$\xi=-1$

\title{
Role of Social Media Optimization in Digital Marketing with special reference to Trupay
}

\author{
Seema Sahai ${ }^{*}$, Richa Goel ${ }^{2}$, Priyanka Malik ${ }^{3}$, Chitra Krishnan ${ }^{4}$, Gurinder Singh $^{5}$, Chitra Bajpai ${ }^{6}$ \\ 1,2,3,4,5,6 Amity International Business School, Amity University, Noida, India \\ *Corresponding author E-mail: ssahai@amity.edu
}

\begin{abstract}
Social media optimization has been used by many organizations in the recent years, after the growth of Internet, for enhancing the growth and profits of their business. This paper discusses some of the strategies of digital marketing adopted by Trupay after the period of demonetization in India.

SMO (Social Media Optimization) can be defined as the process of increasing the popularity and awareness of the product in the minds of the people. It is basically a marketing tool which helps in the promotion, marketing and sale of the product. Digital marketing is the method of promoting a product or a brand using electronic media like Mobile marketing, E-mail marketing etc..
\end{abstract}

Keywords: Social Media; Optimization; Digital Marketing; Mobile Marketing; Product

\section{Introduction}

With the ease in the access of Internet by people, it has been noticed that almost all mobile phone owners have use the Internet in some form or the other. Taking advantage of this telephonic boom, a new venture with the name of Trupay developed a mobile-based application that allowed users to send and receive money directly to and from their bank account using just the mobile number of the beneficiary. With the motive of making a place in the financial world, it developed one of the most secured and bank agnostic platform to ease the transfer of funds within the Indian banks.

Trupay was formed in November 2015, with the aim to enable the transaction of money between individual bank accounts and stores both online as well as of f $1 \mathrm{in} \mathrm{e}$. They wanted to remove the hassle of swiping one's debit card or filling long columns of card details and IFSC code by offering an easy, secure \& seamless payment experience for everyone. This process further lead to the removal of intermediaries between the customer and their bank due to which is why it became popular with the common people. Another reason for its popularity is the hassle free payment through smartphones

\subsection{Challenges faced by Trupay}

One of the major challenges faced by Trupay was creating their own market space and existence. Their mobile application was not much known amongst people. In the first six months it had only one lakh Google installs. Due to this challenge, Trupay focused to build their presence with the help of social media marketing. Managers should be aware of the importance of social media sites in influencing online shopping by identifying and targeting different types of customers and taking initiatives to recognize and highlight customer interests [1].
Their first move was to run various campaigns on Facebook, Twitter and LinkedIn. As one of their promotional tactics on Facebook, they conducted various kinds of contests. All contestants had to first download their app to take part in the competitions. The motive behind this Facebook campaign is to increase downloads of their app and also engagement and traffic on their Facebook page. Through LinkedIn, they were targeting the merchants, who were their primary customers. Their focus was on the concept of UPI (Unified Payment Interface) through which they were trying to create awareness about the application amongst the users.

Another challenge for Trupay was one of its biggest competitors Chillr. Chillr is also a mobile based payment application based on UPI introduced by HDFC bank. Though their concept is same, they have only one sponsored bank whereas, Trupay has affiliation with 24 banks.

\subsection{The Concept of Unified Payments Interface (UPI)}

The NPCI(National Payment Corporation of India), which is formed by the Reserve Bank of India introduced UPI. The communication system in India has been revolutionized due to the fast growing mobile connectivity. In India the growth from the very limited landline users to more than a billion. mobile connections has been seen across the country. Most correspondence is done through the mobile phone.

From almost no telephone access, Indians went straight into utilizing cellular telephones as an integral part of their lives in a gigantic way. A mix of administrative and open business sector approach permitted numerous organizations to contend and give best value to clients. Smartphones as well as telephones which are easy and convenient to use and available at very low cost, gave way to the market for such apps like Trupay 


\section{Digital Marketing}

This refers to the use of digital technologies like the Internet for marketing and promotions of products and services by an organization. Marketing refers to the creation of demand for one's product or service. If all goes well, this demand should translate into sales and, ultimately, revenue.

Digital marketing helps in the creation of this demand by using the Internet on digital devices through an interactive medium and innovative ways. The digital media allows of exchange of money as well as exchange of value. Content marketing is a powerful way of creating value. Practical design and implementation has, so far, typically been the result of trial and error [2].

The term digital marketing was first used in the 1990s. It became more sophisticated in the 2000s and the 2010s, the proliferation of devices' capability access digital media at almost any given time has led to great growth of digital advertising; statistics produced in 2012 and 2013 showed that digital marketing was still a growing field. There are many terms for Digital marketing like 'online marketing', 'internet marketing' or 'web marketing'.

Digital Marketing can be of the following kinds:

i. Email Marketing: This is first form of digital marketing technique. Here organizations send regular updates to the customers about their products and services. Many a time these mails are not entertained by customers and are termed as spam.

ii. SEO (Search Engine Optimisation) SEO is the way of increasing a website's visibility in online search engines such as Google, Yahoo etc.

iii. PPC (Pay Per Click) This is a paid search, also known as PPC, it is the management of paid advertisements in the search results of a search engine. Paying per click means you only pay when a prospective customer clicks on your link.

iv. Online Advertising: This differs from PPC in that you are advertising on other peoples' websites.

v. Blogging, RSS \& News Feeds Blogging involves not just writing blogs, but creating a blogging strategy that brings together SEO, PR, social media and web design. Companies can use online reputation systems in order to provide the right online incentives to the right online customers [3].

vi. Viral Marketing: Viral marketing combines many elements of the marketing mix. Some call it 'content marketing', as it always involves disseminating an element of content across multiple channels.

\subsection{Role of Digital Marketing}

1. Digital Marketing is Less time taking: As compared to traditional marketing, this type of marketing takes very less time. Traditional marketing can take many days depending on the complexity of the work. Digital marketing is faster

2. Target audience is more: Because reach is wide audience is wider

3. Cost is less: Fewer people are involved. Developing and implementing it is much faster than traditional advertising

4. Suited for all categories of business: As communication with customer is the main motive of advertising, digital marketing plays a great role in all types of businesses

\subsection{Changes in communications characteristics}

- One-to-many to one-to-some and one-to-one - Tailored, personalized communications are possible

- One-to-many to many-to-many communications- Digital provide an opportunity to form communities automated media
- 'Lean-back' to 'lean-forward' - High involvement, high attention

- Old communications tools to new tools-Such as search engine marketing and affiliate marketing

- Push to pull- Consumers actively seek information rather than it being delivered

- Monologue to dialogue-Digital media are interactive media; measurement is possible through web analytics

\subsection{Benefits of Digital Marketing}

- Provides a new channel for communication (dialogue)

- Cost Effective

- Fast

- Flexible

- National and International(reachability)

- Retain Customer Loyalty

- Measurable

- Direct, there does not have to be a connection to third parties

\subsection{Understanding the digital customer}

- Digital technology in every form. Tablets, email, smartphones, mobile apps, computers, iPods, net books, augmented reality, QR Codes and many more technological developments have changed the way we communicate.

- The digital life has not replaced the real person to person" lifestyle but rather enhanced life to be more convenient and dynamic

\section{Social Media Marketing}

Social media is a phenomenon that has transformed the way we connect, we communicate, we find, we learn \&we access things. In the current scenario, we are observing that the use of Internet \& social media is growing day by day in our community \& specially becoming popular among youth. Now there are various platforms available with people through which they can connect with the world in a single click. The use of blogs and social networking sites lead to instant access to the outside world through which they can easily connect with each other.

Social Media provides quality information about the world. In the same way social networking sites provides the rich information about the people, \& their networks which can be utilized for various personal \& professional purposes. Internet buying and commerce has a global reach and several corporations count on global markets for expansion and growth [4]. Indians were very active in performing their day to day activities offline. But gradually with the passage of time social media started positioning itself in the minds of Indian people. After Sixdegrees.com, Orkut came into existence in 2002, and it performed really well in India market with the user share of $64 \%$ in India. . The initial target of Orkut was youth between the age group of 11 to 18. It became popular among school students.

Facebook, a well renowned social networking site of current time was launched in 2004 with the objective of linking people. Though they were doing the same thing as Orkut was doing, however they were far better than them. They introduced various other features in their site. Soon, Facebook become a tough competition for Orkut. What Facebook did was they started expanding to universities and colleges. Like this Social media \& social networking sites started gaining a prominence in the lives of people in India. Now, India is ranked seventh largest market worldwide for social networking.

With the rapid increase in Social media networking, Internet usage also increased in India. Today, there are more than 243 million users 
of Internet in India. From personal life to professional life, social media marketing was spreading everywhere. LinkedIn is one such professional site where the professionals can interact with each other for fulfilling their business purposes.

Social media created a need for the offline businessmen to promote their business online. Slowly and gradually changes started emerging in performing business. People started selling their products and services online as well. Social media created a need of digital marketing in India. It has transformed the way we think, we use the Internet. Internet has become a platform for buying and selling products \& services. With the help of digital marketing, advertisement styles have also changed. It is cheaper and more convenient than the traditional method of advertising. Digital marketing has also been witnessing a steady growth in India. As per the estimates, the online advertising market is going to touch Rs. 2,938 Crore. E-commerce has reached Rs. 1, 07, 800 crore which explains the emphasis of the Indian population on E-retailers like Flipkart, Myntra, Snapdeal, Amazon etc.

\subsection{Trupay}

It aimed at revolutionizing the Indian payments scenario by offering an easy, secure \& seamless payment experience for everyone. Unlike other payment companies, Trupay believed that there should be no intermediaries between the customer and the bank so Trupay had done away with all the layers. Benefit for customers was that they could move real money in real time \& for merchant is that there would be no traditional settlement cycles, Trupay offered zero settlement duration.

There are various companies working on the payment platforms like Paytm, Mobiwik, Freecharge etc., however the only company, which can be a tough competitor for Trupay, is Chillr. Chillr is a mobile payment application that allows one to send money instantly to anyone in the phone contact list, but as mentioned earlier its limitation is that it is sponsored by only one bank.

Trupay is different from its competitors because they are introducing smart wallet which are actually transformed version of the bank accounts unlike others who are only burdening the customer by creating a virtual wallet which has to be topped up with virtual currency repeatedly. Trupay leverages the finest features of the existing Indian banktransfer set up. Not only that, Trupay authenticates both the transacting parties (sender \& receiver) in the real world so that you always know where your money is going.

Through social media organizations can increase their clientele and thereby increasing sales. It also helps organizations to monitor their reputation, generate leads and increase traffic on sites by spreading brand awareness i.e. it informs people about all details of the organization's product and service

\section{Literature Review}

Smith and Swinyard (2001) have developed an instrument that encompasses interests and opinions towards the Internet, as well as webspecific behaviors that increase the likelihood of obtaining relevant online segments [5].

Talita Da Silva, Anna Friberg (2017), according to the authors, social media is a tool of which allows a person to socialize better and pursue social happiness, which will consequently result in individual pleasure. They mentioned that social media would be noted as a tool used by man to pursue "Universal Benevolence" and future research should concentrate on further understanding this relationship [6].

Michael A. Stelzner (2016), the author highlighted significant changes which had taken place in digital marketing since 2015. In his study more than 5000 marketers were surveyed with an aim to find out how social media was promoting their businesses. His findings showed that more than $90 \%$ of marketers revealed that digital and social media is actually playing a crucial role in promoting their business [7].
Andrew T. Stephen (2016), The research conducted by the author tried to determine how much online word of mouth through social media, effected the perception of consumers. Their research shows that consumer tend to seek maximum information from various media about the product to come to a particular decision of purchasing the product [8].

Tripti Dhote, Yatin Jog, Nutan Gavade, Gesu Shrivastava $\mathbf{2 0 1 5}$, the authors try to understand the relation between digital marketing and academics. Their research shows that there is a high degree of awareness about the concept of digital marketing and academics in the targeted group and that the digital media can play a vital role if the students take the word of mouth seriously [9]

Rita Sachdev (2015), the author studied the role of e-commerce in the Indian Economy. The research shows that though e-commerce plays an important role in the Indian Economy its future in India is unpredictable [10].

Parul Deshwal (2015), the author observed the e-marketing environment, analyzed the advantages and disadvantages of e-marketing and also analyzed the future of e-commerce and its growth. They concluded that the future belongs to e-marketing but is not limited to it. Though ecommerce is advantageous in several manners, it also has some disadvantages, which cannot be neglected at any cost [11].

Asams V.K. (2015), While conducting primary research on Indian consumer buying behavior through a survey of 250 respondents, the author came to the conclusion that Indian buyers are high information seekers i.e. they seek a lot information before indulging into any buying. Indian market is a value-oriented market i.e. buyers would be ready to pay a price certain for product if they are getting value for their money. People have started bending towards online marketing to get information about the products. Word of mouth of friends, family and relatives, however, is given more preference than online reviews. The limitation of this research was that the research was conducted only amongst the students of the college. Word of mouth is generally accepted as the most effective form of advertising [12].

Trusov, Bucklin \& Pauwels (2009) in their research stated that "social networking sites can be described as networks of friends for social or professional interactions". They focused on the point that in recent years, social networking sites and social media have increased in popularity, at a global level. For instance, Facebook is said to have more than 10 billion active users now [13]

Akrimi \& Khema khem (2012) stated that online social networks have profoundly changed the propagation of information by making it incredibly easy to share and digest information on the internet. They said "social media facilitated the interactions and the information sharing between the Internet users" [14].

Hanna, Rohm, \& Crittenden (2011) stated that the unique aspects of social media and its immense popularity have revolutionized marketing practices such as advertising and promotion [15].

Mangold \& Faulds (2009)stated in their research that social media has also influenced consumer behavior from information acquisition to post-purchase behavior such as dissatisfaction statements or behaviors and patterns of Internet usage [16].

Laroche (2012)stated that "in an online environment, people like the idea of contributing, creating, and joining communities to fulfill needs of belongingness, being socially connected and recognized or simply enjoying interactions with other like-minded members. The much higher level of efficiency of social media compared to other traditional communication channels prompted industry leaders to state that companies must participate in Facebook, Twitter, MySpace, and others, in order to succeed in online environments." [17] 
Williams \& Williams (2008) has mentioned that "more industries try to benefit from social media as they can be used to develop strategy, accept their roles in managing others' strategy or follow others' directions." [18]

Mersey, Malthouse, \& Calder(2010) explains that social media websites provide an opportunity for companies to engage and interact with potential and current consumers, to encourage an increased sense of intimacy of the customer relationship, and build all important meaningful relationships with consumer especially in today's business environment when consumer loyalty can vanish at the smallest mistake [19].

\section{Research Work:}

\subsection{Objectives}

1. To study the importance of social media in marketing of Trupay as a brand.

2. To study the market potential of Fintech industries.

3. To identify the strategies of Fintech players.

4. To create awareness about Trupay

\subsection{Research Methodology}

A random sample of 50 persons was taken from the National Capital Region to determine the brand awareness of Trupay. Secondary data was also taken from sourceslikeBooks,Journals,Magazines,Newspapers,IndustryAssociationR eports, Government Publications, Websites, Internet, On-line databases etc. were used.

\subsection{Research Analysis:}

From Secondary sources, the following conclusion was derived:

\subsubsection{Internet usage:}

- Total users may increase to500 Million by 2018

- India will get to be bigger than the US as far as number of Internet users in the long run

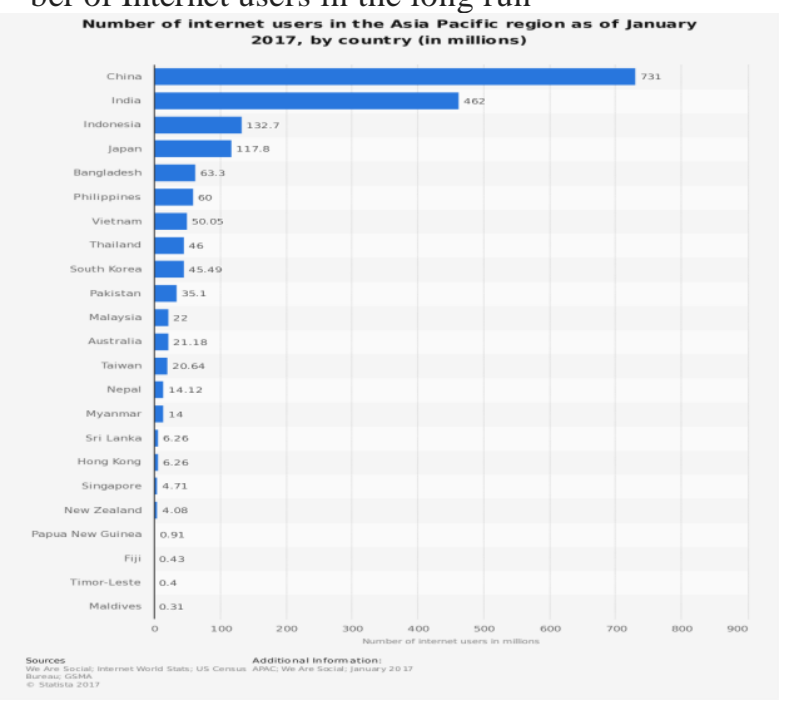

Fig 1. Source: www.statistica.com

\subsubsection{Mobile Usage:}

There has been a surge in the mobile usage, with the rise of the Smartphone era maximum numbers of individual's access web and online networking from their cellular telephones. As per BCG report on Indian Internet, the mobile penetration of dynamic web clients is 550 Million. It is of foremost significance to make your web pages and sites portable advanced. As per an article in Live-
Mint there are absolute 92+ Million active online networking clients through their phones, which is only $41 \%$ of the total mobile internet.

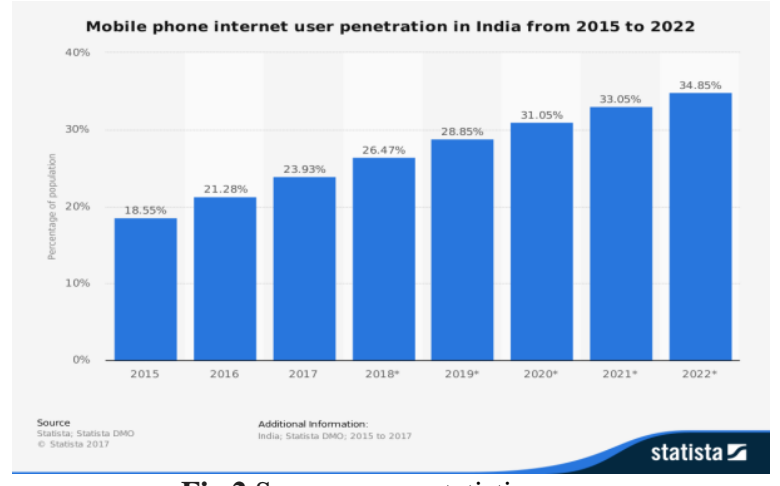

Fig 2 Source: www.statistica.com

\subsubsection{Digital Media in India}

Social media has changed the importance of customary method of promoting and advertising, Digital Advertising has been seeing a relentless development in India. Internet market in India is supposed to reach 7,000 crore by end of this year as per an article in The Hindu. The E-commerce committee report says E-Commerce in India is expected to reach $\$ 24$ billion (Rs 1,07,800 crores) by the year 2017, which clarifies the accentuation on E-retail locations like Flipkart, Myntra and so forth and the incorporation of purchase catch in informal organizations, for example, Twitter and Facebook

\subsubsection{Social Media in India}

Indians are exceptionally dynamic on various social networks and $88 \%$ of users offer substance on their social profiles. Facebook is the most per used in formal organization on online networking with a substantial base of 100 Million users, obviously in India and it is continuously rising. More than $90 \%$ of those users access Facebook on their phones as per the e-marketer online newsletter. A news in the Indian Express said that the total Twitter clients in India are 35 Million and from this base $80 \%$ of users access it on their phones. LinkedIn has 42 Million Indian subscribers, of the aggregate 300+ Million subscribers as per the April 2017 issue of LiveMint. Channel Infoline says that out of the aggregate limp of 70 Million clients in Pinterest, 5.5 Million are from India.

In India people are very active on their social networks almost 90\% share their genuine profiles on the same. As per David Chaffey in Smart Insights, his compilation of the most popular social networks worldwide prepared by Statista gives a clear picture that Facebook is supreme. This won't be a shock to anyone! With over 1,870 million active users worldwide, it holds an $18 \%$ market share, $7 \%$ more so than its closest competitor, the Facebook-owned, WhatsApp.

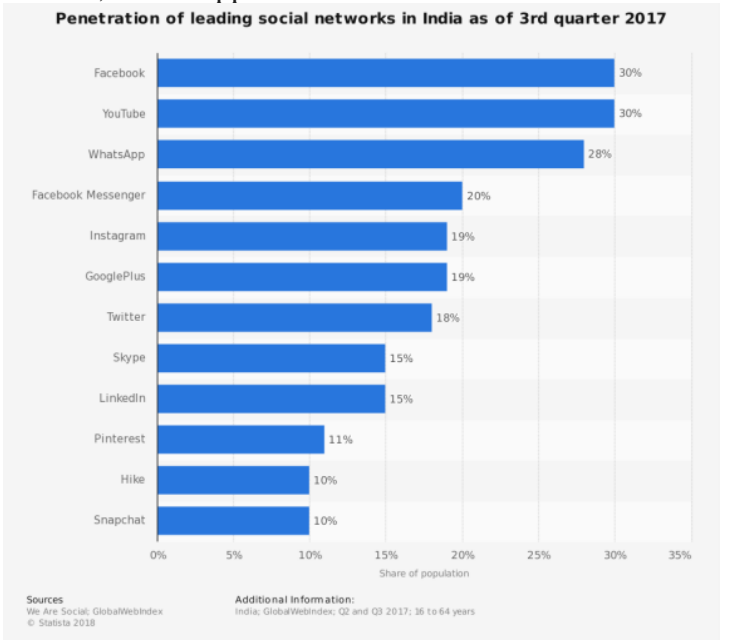

Fig. 3. of social network ranking in India . Source: Statista 
As we know Trupay is a startup and working on its positioning strategy. So, in order to create awareness amongst people and create a buzz in the minds of the consumers, Trupay launched a campaign through two social media platforms i.e, Facebook and Twitter. It was more of an awareness campaign to make people aware about the services and Trupay as a brand.

Before starting the campaign, their Facebook page was known to around 600 people and on Twitter, Trupay had around 5 followers. After the campaign the figures changed from 600 to $5 \mathrm{k}$ active likes on Facebook and on Twitter the followers increased from 5 to 80 . The survey conducted on targeted audience with a sample size of 50 people was aimed to analyze the results to check whether there has been any change in brand awareness or not.

First three questions were personal questions which covered the Name, E-mail id and occupation of the respondent. Therefore we will start the analysis from the fourth question.

I. To study the importance of social media in marketing of Trupay as a brand.

(a) Do you know Trupay?

Table 1. Awareness Response

\begin{tabular}{|c|c|c|c|}
\hline Options & Yes & No & Total \\
\hline No. of Respondents & 24 & 26 & 50 \\
\hline
\end{tabular}

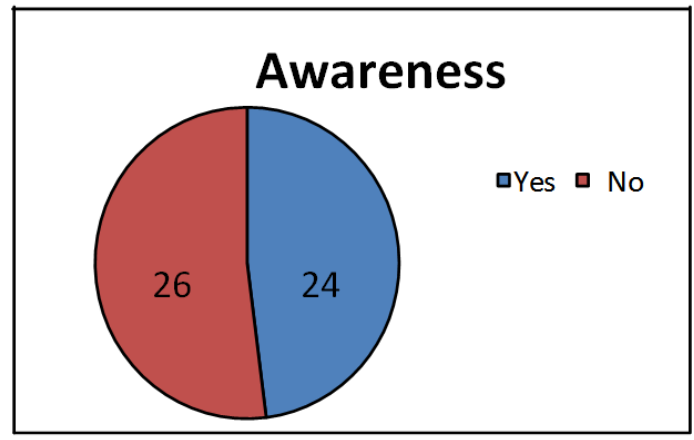

Fig. 4. Awareness of Trupay

This result suggests that awareness level was still not as high as expected after using social media networking.

(b) How did you get to know about Trupay?

1. Friend

2. Facebook

3. Twitter

4. Others

Table 2. Source of Awareness

\begin{tabular}{|c|c|c|c|c|c|}
\hline Options & Friend & Facebook & Twitter & Others & Total \\
\hline No. of Respondents & 2 & 18 & 2 & 2 & 24 \\
\hline
\end{tabular}

Fig. 5 shows that majority of people came to know of Trupay through Facebook and very few (2\%) from Twitter.

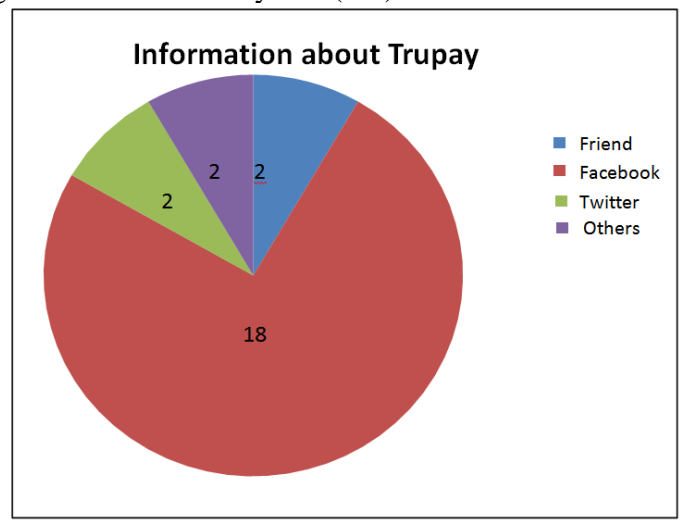

Fig 5: Introduction to Trupay (c) How do you rate Trupay as a payment application from 1-5? (1 being the best and 5 being the worst)

Table 3. Rating of Trupay

\begin{tabular}{|c|c|c|c|c|c|}
\hline Rank & $\begin{array}{c}1 \\
\text { (Excellent) }\end{array}$ & $\begin{array}{c}2 \\
\text { (Good) }\end{array}$ & $\begin{array}{c}3 \\
\text { (Neutral) }\end{array}$ & $\begin{array}{c}4 \\
\text { (Not } \\
\text { Satisfactory) }\end{array}$ & $\begin{array}{c}5 \\
(\mathrm{Bad})\end{array}$ \\
\hline Response & 8 & 14 & 2 & 0 & 0 \\
\hline
\end{tabular}

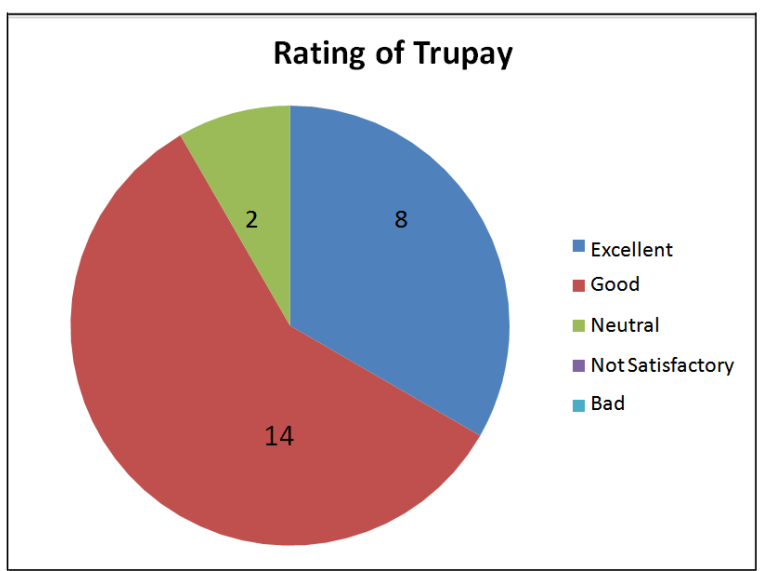

Fig. 4: Rating of Trupay

The survey result ranking depicts that the Trupay is a hit in the market, as the figures of good and excellent parameter are extremely good for a new brand to be showcased with.

II. To study the market potential in Fintech industry.

If we compare the facts and figures of Trupay and Chillr, then we see that Trupay has around 1,00,000 downloads in 6 months from the launch of app where as Chillr was launched in 2011 and still have around 10 lakh downloads on Google app store. So we can see that after the introduction of UPI, the revenue model for such companies like Trupay would be a boost for sure.

III. To identify the strategies of fintech players

Big Fintech player like Paytm works on the principles of Affiliate marketing. It is one of the oldest forms of marketing in which you refer someone to any online product and when that person buys the product based on your recommendation, you receive a commission. Their revenue generation model focuses on merchants and customers, whereas Trupay's revenue model focuses on merchants only. A big player like Paytm is also doing the same thing, apart from this Paytm is also charging people for the withdrawal of their own money from their own wallets.

Paytm is charging $3 \%$ from a customer for the withdrawal of money from their own paytm wallets. They are making lots of money from this only. Whereas with Trupay one can transfer money directly from one's bank account to receivers' bank account and that too with only the mobile number of the receiver. Apart from that with Trupay one can easily earn bank interest on their money kept in bank accounts.

\subsection{Findings}

- It has been observed that Trupay was very popular amongst people

- As per the survey done, there is an increase in customer awareness about Trupay.

- Consumers are happy using Trupay

- Currently 1, 00, 000 users are using Trupay in just 6 months

- Social media is a big reason behind Trupay's success

- Facebook page of Trupay has the most traffic as of now among all Trupay's social media platforms

- Twitter is also growing but at a small rate. 


\subsection{Recommendations}

- Company should start focusing on other social media platforms like Twitter and LinkedIn

- Trupay should target merchants using professional platforms like LinkedIn

- Trupay should start making its presence on blogs as well

- It should tie up with famous and reputed top most Fintech bloggers.

- They should run more and more campaigns to create a buzz in the minds of the users.

- Trupay should improvise on Apple App store SEO.

- It should be available on windows as well

\subsection{SWOT Analysis of Trupay}

\subsubsection{Strength}

- A Buyer can make the payment directly to the merchant at the time of purchase from his mobile phone

- Secured payments

- There are no intermediaries in between. The payment amount gets directly transferred from the buyer's account to the seller's account. Approval of VISA or Master won't be required. So it is authenticated as everyone will know where the money is going. It is a hassle free, secure and seamless payment option

- Real money transfer in real time

- Cost effectiveness for both parties (Buyers \& Sellers) Time efficient

- Easy and convenient ( No wallets \& No cards) Multiple account access

- No per day transaction amount limit (50000 in chillr) No limit to number of transactions a day ( 25 in chillr)

- Many number of beneficiaries can be added in an account (only 5)

\subsubsection{Weakness}

- Promotion (Not much known, need to work on its promotion strategies)

- Limited details

- Money Transfer Limit(up to Rupees 5000 in one go)

\subsubsection{Opportunities}

- Analyze KPI (Key performance indicators)

- USP (Unique selling proposition) First mover advantage

- Create solid landing pages ( which should be user friendly \& straight to the point) Developing a social media plan

- Increase its money transfer limit Repeat transfer with just one swipe

\section{Conclusion}

As per the study it is indicated that Trupay is very popular amongst people. Trupay is using various ways to leverage social media presence and improving their clientele. Their market potential is so high especially after the demonetization in India that it will do very well amongst the masses. The government is also promoting such agencies, as they want to move the nation to a cashless society.

Trupay's revenue model focuses on merchants only. This gives an encouragement to the merchants to promote the system. As seen in the SWOT analysis, the strengths of Trupay outweigh the weaknesses manifold. This again assures that it will stay in the market in the days to come.

\section{References}

[1] Dumitrescu, L., Stanciu, O., Tichindelean, M., \& Vinerean, S. (2012), Researching the Students Cognitive Space-A Relevant Phase in the Holistic Approach of the Higher Education Institu- tions Management. Far East Journal of Psychology and Business 7, 26-36.

[2] Dellarocas, C. N. (2010). Designing Reputation Systems for the Social Web. Boston U. School of Management Research Paper No. 2010-18.

[3] Hagel, J. (1999), Net gain: Expanding markets through virtual communities. Journal of interactive marketing 13, 55-65.

[4] Al Kailani, M., \& Kumar, R. (2011), Investigating Uncertainty Avoidance and Perceived Risk for Impacting Internet Buying: A Study in Three National Cultures. International Journal of Business and Management 6, 76-92.

[5] Smith, S. M., \& Swinyard, W. R. (2001, June). The identification of shopping behaviors among Internet users. In Cardiff Business School, World Marketing Congress.

[6] Da Silva, T., \& Friberg, A. (2017). A Literature Review of the Field of Social Media in Retail (Dissertation). Retrieved from http://urn.kb.se/resolve?urn=urn:nbn:se:hh:diva-33330.

[7] Stelzner, M. (2016). 2016 Social Media Marketing Industry Report. Social media examiner, 1-56.

[8] Lamberton, C., \& Stephen, A. T. (2016), A Thematic Exploration of Digital, Social Media, and Mobile Marketing: Research Evolution from 2000 to 2015 and an Agenda for Future Inquiry. Journal of Marketing 80, 146-172.

[9] Dhote, T., Jog, Y., Gavade, N., \& Shrivastava, G. (2015). Effectiveness of digital marketing in education: An insight into consumer perceptions. Indian Journal of Science and Technology 8 , 200-205.

[10] Sachdev, R. (2015), Role of e-commerce in Indian Economy, International Human Research Journal.

[11] Deshwal, P. (2015). E-Marketing: Challenges And Opportunities For The Marketers. International Journal of scientific research and management (IJSRM) 3, 3747-3753.

[12]

[13] Trusov, M., Bucklin, R. E., \& Pauwels, K. (2009). Effects of word-of-mouth versus traditional marketing: findings from an internet social networking site. Journal of marketing 73, 90-102.

[14] Akrimi, Y., \& Khemakhem, R. (2012). What DriveConsumers to Spread the Word in Social Media? Journal of Marketing Research \& Case Studies 2012, 1-14.

[15] Hanna, R., Rohm, A., \& Crittenden, V. L. (2011). We're all connected: The power of the social media ecosystem. Business horizons 54, 265-273.

[16] Mangold, W. G., \& Faulds, D. J. (2009). Social media: The new hybrid element of the promotion mix. Business Horizons, 52, 357-365.

[17] Laroche, M., Habibi, M. R., Richard, M. O., \& Sankaranarayanan, R. (2012). The effects of social media based brand communities on brand community markers, value creation practices, brand trust and brand loyalty. Computers in Human Behavior, 28, 1755-1767.

[18] Williams T. and Williams R., (2008). Adopting social media: Are we leaders, managers or followers?. Communication World 25, 34-37.

[19] Mersey R., Davis, Malthouse E. \& Calder B., (2010). Engagement with Media, Journal of Media Business Studies 7, 39 -56. 